\title{
Economic Policy Uncertainty and U.S. REITs Herding Behaviors
}

\author{
Wenyuan $\mathrm{Lin}^{\mathrm{a},}{ }^{*}$ and Yuechen $\mathrm{Li}^{\mathrm{b}}$ \\ Beijing Normal University, Zhuhai, China \\ alinwy@bnuz.edu.cn, byichen00827@163.com \\ *Corresponding author
}

Keywords: Economic policy uncertainty, REITs, Herding behavior, Quantile regression.

\begin{abstract}
This study examines economic policy uncertainty (EPU) on U.S REITs herding behaviors. The empirical findings indicate that EPU can explain the varieties of herding effect in the REITs market. The negative effect of EPU is considered in the U.S REITs herding. The REITs market is able to avoid the impact of uncertainties in economic policies. In addition, herding behaviors among real estate market investors show a positive correlation between EPU and CSAD during market turbulence from the quantile regression empirical results. More importantly, herding behavior is still detected in periods of more severe market volatility.
\end{abstract}

\section{Introduction}

The dot-com bubble and the subsequent stock market crash shook investor confidence to the financial markets in general. Under these circumstances, investors withdrew their funds from financial markets and turned to alternative investments, such as real estate [1]. Nowadays, because of the impact of the subprime mortgage crisis on the global market, it has been an important research issue for real estate investment behavior in recent years. Among them, herding behavior is one of the most important topics on real estate investment trusts (REITs) market [2, 3]. Herding behavior refers to the behavior of investors who ignore their own personally-held information in favor of investments based on mainstream public opinion [4]. It is noteworthy to investigate herding behavior because it could drive market prices away from fundamental values and present profitable trading opportunities [2]. So that Herding behavior is an important phenomenon to examine and to document from a regulatory as well as an investment perspective.

Baker develops a new index of economic policy uncertainty (EPU) based on a number of criteria [5]. His empirical results indicate that the measure of policy uncertainty foreshadows declines in investment, output, economic growth, and employment in the United States. Economic or political shocks are seen as an important source of uncertainty for firms, because their costs, sales, and profits will be greatly affected. Many more research studies subsequently have focused on the financial/capital market effect from EPU [6, 7, 8, 9, 10, 11, 12].

In this paper, we designate the EPU as an indicator for policy information risk to explain differences and changes to herding behavior in U.S. REITs market. Our main results can be summarized as follows. First, we show that EPU can explain the varieties of herding behavior in the REITs market. The REITs market is able to defense the impact from policy uncertainties in United State. Relatively, the investors of U.S. REITs are rational and careful to understand and handle the impact of uncertainties in economic policies. Second, herding behavior is present when the market is under intense volatile conditions by quantile regression model. More importantly, we can indicate that herding behavior still exists when the market is experiencing volatile conditions.

\section{Literature Review}

Previous studies had been illustrated that investors face uncertainty not only from volatile prices in traditional markets, but also from a less conceivable form of uncertainty over policy changes [13, 14]. Although the empirical evidence on linking public information with capital market investment 
is still accumulating. Brzeszczyński, had reviewed previous empirical papers and illustrated three types of policy-oriented announcements and news which are monetary policy announcements, news about IMF programs during financial crises and other public or political news[15]. Following up, Baker develops an EPU index to reveal the level of policy uncertainty which was publicly proposed for the first time in 2011 [5]. The approach to measuring policy uncertainty raises potential concerns about newspaper reliability, accuracy, bias, and consistency. Many empirical studies have employed the EPU index as an indicator of policy uncertainty on capital markets in recent years. The index has received wide acceptance in empirical applications and clearly presented the importance of recognizing policy uncertainty's impact from the macroeconomic perspective $[6,9,16]$.The strategy, announcement and execution of economic policies play an important role in the capital market development as abovementioned. Numerous studies also had examined the relationship between policy uncertainties and real estate market. It can clearly be seen, the policy uncertainty may also lead to affect returns from real estate investment [12]. Antonakakis examines the dynamic correlations between housing market returns and the EPU index [17]. The results reveal negative correlations throughout the empirical window 1987-2014. Anoruo et al. (2017) examine dynamic interactions between EPU and housing market returns for Japan. The authors show the evidence of causality-in-mean from housing returns to EPU for post-crisis period. To summarize the above, the empirical results can be expected that EPU is an important indicator for real estate markets.

Liow reminds investors to pay attention to EPU, interest rate movements, implied volatility and world stock market returns on REITs' volatility connectivity over time [18]. However, based on the characteristics of the real estate market inefficiency. The market performance is not fully susceptible to EPU impacts. Especially in downturn market trend. Lizieri proposes that price differences were attributed to trading imbalance caused by the limited liquidity of the housing market and that the effects of market sentiment might lead to housing market inefficiency [19]. Tsai presents that housing prices efficiently reflected loose monetary policy but did not efficiently reflect a tight monetary policy [20]. The real estate market has characteristics that can differential response to the effect for economic policy. Although previous studies have shown a negative relationship between EPU and real estate market investment (Antonakakis et al., 2015; [12].), there is attraction from the defensive characteristics of the real estate market that can avoid the impact of market sentiment. Accordingly, investment behavior in the real estate market can show rational and performance against policy uncertainties.

In this paper, we consider to re-examine the EPU effect on REITs market herding behavior for United State, which is the most mature REITs market in the world. This paper is based on the conclusions from Zhou [2]. Whereby the expected influence of EPU on the herding behavior is negative, which means investors in U.S. REITs market will make investment decisions more rationally and carefully to deal with the impact of the policy uncertainties. The hypothesis of this paper thus follows.

Hypothesis: EPU has a negative effect on herding behaviors in U.S. REITs market.

\section{Empirical Processing and Results}

The research period for our study is from January 2004 to December 2014. We refer the data frequency from Zhou and employ weekly in the present study [2].. ${ }^{1}$ The EPU index constructed by Baker is acknowledged to be a credibility rating of real policy uncertainty [5]. The numerical data could be used on website (http://www.policyuncertainty.com/index.html). The cross-sectional absolute deviation of returns (CSAD) is the primary measurement of herding behavior in most studies (Lin et al., 2018) as follows:

\footnotetext{
${ }^{1}$ Zhou and Anderson (2013) examine herding behavior in the U.S. REIT market using daily, weekly, and monthly data and test the robustness of each frequency. They find that empirical results from the three frequencies are fairly consistent.
} 


$$
C S A D_{t}=\frac{1}{N} \sum_{i=1}^{N}\left|R_{i, t}-R_{m, t}\right|
$$

Here, $R_{i, t}$ represents the stock return of REIT company $i$ at time $t$, and $R_{m, t}$ represents the cross-sectional average return of $N$ stocks at time $t$. We obtained these REITs data from The Center for Research in Security Prices database (CRSP). The equation for the CSAD model was proposed by [21]. Philippas et al. (2013) enhance the Chang et al. (2000) model to include macroeconomic variables to verify herding behavior. Based on their consideration, we consider the EPU index as a target of our examination in this model to determine whether policy uncertainty decreases herding effect in REITs. If so, the coefficient $\left(a_{3}\right)$ should be positive and significant. The empirical model as follow:

$$
C S A D_{t}=a_{0}+a_{1}\left|R m_{t}\right|+a_{2} R m_{t}^{2}+a_{3} E P U_{t}+\varepsilon_{t}
$$

Here, $E P U_{t}$ represents EPU in the U.S. Incorporating the concept of quantiles into the model results in a modified version of Eq. (2a), as follows:

$$
\operatorname{CSAD}_{t}(\tau)=a_{0}(\tau)+a_{1}(\tau)\left|R m_{t}\right|+a_{2}(\tau) R m_{t}^{2}+a_{3}(\tau) E P U_{t}+\varepsilon_{t}(\tau)
$$

By incorporating the concept of quantiles into the regression model, we can examine whether EPU affects herding behavior in REITs at different turbulent market levels ([2]; Lin et al., 2018). In Table 1 we see that EPU decreases (increases) the likelihood of herding behavior in the REITs market. We also consider the EPU indicator, which results in Eqs. (2a) and (2b). Overall, the results of OLS show that the coefficients of EPU $\left(a_{3}\right)$ are positively and significantly related to CSAD $(t$-statistic $=7.064)$. The empirical results, on average, indicate that policy uncertainty in the REITs market decreases herding behavior. The quantile regression empirical results, as Panel B reports, provide two important focal points. First, the coefficients of EPU show that herding behavior decreases as EPU rises (positive and significant). The explanatory power of EPU is obtained as market turbulence increases. The results accounting for incorporating EPU to examine herding behavior among real estate market investors show a positive correlation between EPU and CSAD during market turbulence (high quantiles). Higher EPU is more likely to reduce market herding behavior. Second, the empirical results exhibit that herding behavior is present when the market is under intense volatile conditions (at higher quantiles; in most cases above the 85\% quantile). We consider the EPU effect for herding behavior, and it becomes pronounced at higher market turbulent levels. In other words, herding behavior still exists when the market is experiencing volatile conditions. This also provides the benefits of using quantile regression to study herding and the consistent results with the findings of previous studies ([2]; [22]; Lin et al., 2018). These results support Hypothesis and illustrate that investors of U.S. REITs will make investment decisions more rationally and carefully to deal with the impact of the policy uncertainties. These results also reveal that the REITs market can help impede the negative impact from policy uncertainties in the United States.

\section{Summary}

Previous studies had revealed the characteristics of defensive in real estate market ([23]; Lizieri et al., 2012; [20]). The inefficiency characteristic of real estate market form defensive quality for capital market. Today, the market information can be delivered quickly, it is interesting to recognize the impacts of market information risk on real estate market from economic policy perspective. In this paper, we examine EPU effect on U.S. REITs market. The EPU index as the proxy variable for economic policy risk is to verify whether herding behavior reflects the impact of policy uncertainty in the U.S. REITs market. The empirical results, first of all, show that the EPU index has important explanatory power for herding behavior in the real estate market. After that we find that an increase in EPU is likely to eliminate in market herding behavior. And the results show that herding behavior 
decrease while the influence of EPU increasing.

\section{Acknowledgements}

This research was financially supported by the Guangdong Province Innovative Talents Project, China (Grant Number: 201712012QX) and BNUZ “Ability to Promote” Research Program.

\section{References}

[1] N. Philippas, F. Economou, V. Babalos, A. Kostakis, Herding behavior in REITs: Novel tests and the role of financial crisis, International Review of Financial Analysis. 29 (2013) 166-174.

[2] J. Zhou, R.I. Anderson, An empirical investigation of herding behavior in the US REIT market, The Journal of Real Estate Finance and Economics. 47(1) (2013) 83-108.

[3] W.Y. Lin, M.H. Wu, M.C. Chen, Asymmetry Herding Behavior of REITs: Evidence from Information Demand, Journal of Risk. 21(2) (2018) 1-39.

[4] S. Bikhchandani, S. Sharma, Herd Behaviour in Financial Markets, IMF Staff Papers. 47(3) (2001) 279-310.

[5] S.R. Baker, N. Bloom, S.J. Davis, Measuring economic policy uncertainty, The Quarterly Journal of Economics. 131(4) (2016) 1593-1636.

[6] L. Pástor, P. Veronesi, Uncertainty about government policy and stock prices, The Journal of Finance. 67(4) (2012) 1219-1264.

[7] N. Antonakakis, I. Chatziantoniou, G. Filis, Dynamic co-movements of stock market returns, implied volatility and policy uncertainty, Economics Letters. 120(1) (2013) 87-92.

[8] G. Nodari, Financial regulation policy uncertainty and credit spreads in the US, Journal of Macroeconomics. 41 (2014) 122-132.

[9] J. Brogaard, A. Detzel The asset-pricing implications of government economic policy uncertainty, Management Science. 61(1) (2015) 3-18.

[10]X.L. Li, M. Balcilar, R. Gupta, T. Chang, The causal relationship between economic policy uncertainty and stock returns in China and India: evidence from a bootstrap rolling window approach, Emerging Markets Finance and Trade. 52(3) (2016) 674-689.

[11]E. Anoruo, U. Akpom, Y. Nwoye, Dynamic Relationship between Economic Policy Uncertainty and Housing Market Returnsin Japan, Journal of International Business and Economics. 5(2) (2017) 28-37.

[12]G.C. Aye, Causality between economic policy uncertainty and real housing returns in emerging economies: A cross-sample validation approach, Cogent Economics \& Finance. (2018) Forcecoming.

[13]J.S. Ahlquist, Economic policy, institutions, and capital flows: Portfolio and direct investment flows in developing countries, International Studies Quarterly. 50(3) (2006) 681-704.

[14]S. Fuss, J. Szolgayova, M. Obersteiner, M. Gusti, Investment under market and climate policy uncertainty, Applied Energy. 85(8) (2008) 708-721.

[15]J. Brzeszczyński, J. Gajdka, A.M. Kutan, Investor response to public news, sentiment and institutional trading in emerging markets: A review, International Review of Economics \& Finance. 40 (2015) 338-352.

[16]S. Bekiros, R. Gupta, A. Majumdar, Incorporating economic policy uncertainty in US equity premium models: a nonlinear predictability analysis, Finance Research Letters. 18 (2016) 291-296.

[17]N. Antonakakis, R. Gupta, C. André, Dynamic co-movements between economic policy 
uncertainty and housing market returns, Journal of Real Estate Portfolio Management. 21(1) (2015) 53-60.

[18]K.H. Liow, Y. Huang, The dynamics of volatility connectedness in international real estate investment trusts, Journal of International Financial Markets, Institutions and Money. 55 (2018) 195-210.

[19]C. Lizieri, G. Marcato, P. Ogden, A. Baum, Pricing inefficiencies in private real estate markets using total return swaps, The Journal of Real Estate Finance and Economics. 45(3) (2012) 774-803.

[20]I.C. Tsai, The asymmetric impacts of monetary policy on housing prices: A viewpoint of housing price rigidity, Economic Modelling. 31 (2013) 405-413.

[21]E.C. Chang, J.W. Cheng, A. Khorana, An examination of herd behavior in equity markets: An international perspective, Journal of Banking \& Finance. 24(10) (2000) 1651-1679.

[22]T. Lan, Herding behavior in China housing market, International Journal of Economics and Finance. 6(2) (2014) 115-124.

[23]I.C. Tsai, M.C. Chen, The asymmetric volatility of house prices in the UK, Property Management. 27(2) (2009) 80-90. 
Table 1 EPU effect on herding behaviors in the U.S. REITs market

\begin{tabular}{|c|c|c|c|c|c|c|c|c|}
\hline & \multicolumn{2}{|c|}{$a_{0}$} & \multicolumn{2}{|c|}{$a_{1}$} & \multicolumn{2}{|c|}{$a_{2}$} & \multicolumn{2}{|c|}{$a_{3}$} \\
\hline & Coeff. & $\mathrm{t}$ & Coeff. & $\mathrm{t}$ & Coeff. & $\mathrm{t}$ & Coeff. & $\mathrm{t}$ \\
\hline OLS & 0.010 & $8.611^{* * *}$ & 0.456 & $11.977 * * *$ & 0.287 & 1.292 & 0.000 & $7.064 * * *$ \\
\hline \multicolumn{9}{|l|}{ QR } \\
\hline $5 \%$ & 0.010 & $14.906 * * *$ & 0.163 & $5.455 * * *$ & 1.686 & $15.271 * * *$ & 0.000 & $3.201 * * *$ \\
\hline $10 \%$ & 0.011 & $15.404^{* * *}$ & 0.207 & $6.801^{* * *}$ & 1.511 & $12.273 * * *$ & 0.000 & $2.016 * *$ \\
\hline $15 \%$ & 0.011 & $16.752^{* * *}$ & 0.228 & $8.363 * * *$ & 1.410 & $12.603^{* * *}$ & 0.000 & $3.037 * * *$ \\
\hline $20 \%$ & 0.012 & $17.044^{* * *}$ & 0.229 & $7.931^{* * *}$ & 1.389 & $11.778 * * *$ & 0.000 & $3.176^{* * *}$ \\
\hline $25 \%$ & 0.012 & $17.390 * * *$ & 0.241 & $7.417^{* * *}$ & 1.333 & $10.246 * * *$ & 0.000 & $2.998 * * *$ \\
\hline $30 \%$ & 0.013 & $18.010 * * *$ & 0.252 & $7.424^{* * *}$ & 1.278 & 9.333*** & 0.000 & $3.230 * * *$ \\
\hline $35 \%$ & 0.013 & $17.925 * * *$ & 0.300 & $9.191 * * *$ & 1.089 & $8.303 * * *$ & 0.000 & $3.292 * * *$ \\
\hline $40 \%$ & 0.013 & $18.845^{* * * *}$ & 0.309 & $9.412 * * *$ & 1.051 & $7.976 * * *$ & 0.000 & $2.814 * * *$ \\
\hline $45 \%$ & 0.014 & $17.293 * * *$ & 0.336 & $9.610 * * *$ & 0.934 & $6.759 * * *$ & 0.000 & $2.821^{* * *}$ \\
\hline $50 \%$ & 0.013 & $13.583 * * *$ & 0.372 & $8.180 * * *$ & 0.778 & $4.565 * * *$ & 0.000 & $3.033 * * *$ \\
\hline $55 \%$ & 0.013 & $13.033^{* * *}$ & 0.401 & $9.505 * * *$ & 0.643 & $3.736 * * *$ & 0.000 & $3.384 * * *$ \\
\hline $60 \%$ & 0.013 & $13.301^{* * *}$ & 0.439 & $10.625 * * *$ & 0.487 & $2.848 * * *$ & 0.000 & $3.253 * * *$ \\
\hline $65 \%$ & 0.013 & $10.893 * * *$ & 0.463 & $9.084 * * *$ & 0.365 & 1.916 & 0.000 & $3.091 * * *$ \\
\hline $70 \%$ & 0.012 & $7.789 * * *$ & 0.512 & $7.311^{* * *}$ & 0.137 & 0.549 & 0.000 & $2.828 * * *$ \\
\hline $75 \%$ & 0.012 & $8.348 * * *$ & 0.565 & $10.157^{* * *}$ & -0.113 & -0.555 & 0.000 & $3.749 * * *$ \\
\hline $80 \%$ & 0.011 & $6.240 * * *$ & 0.572 & $10.041^{* * *}$ & -0.217 & -1.090 & 0.000 & $3.941 * * *$ \\
\hline $85 \%$ & 0.009 & $6.356 * * *$ & 0.621 & $11.698 * * *$ & -0.485 & $-2.596 * * *$ & 0.000 & $6.152 * * *$ \\
\hline $90 \%$ & 0.008 & $4.840 * * *$ & 0.601 & $9.930 * * *$ & -0.535 & $-2.759 * * *$ & 0.000 & $6.093 * * *$ \\
\hline $95 \%$ & 0.004 & 1.568 & 0.595 & $4.806^{* * *}$ & -0.872 & $-1.848 *$ & 0.000 & $7.065 * * *$ \\
\hline
\end{tabular}

Note: $* * *, * *$, and $*$ denote significance at the $1 \%, 5 \%$, and $10 \%$, levels, respectively. 